\title{
Visual Identity of Malaysian Modern Sculpture
}

\author{
Abdul Halim Husain \\ Faculty of Arts and Music, Universiti Pendidikan Sultan Idris (UPSI), \\ 35900 Tanjong Malim, Perak Darul Ridzuan, Malaysia \\ Email: halimhusain@fskik.upsi.edu.my
}

\begin{abstract}
An artwork is the manifestation of an artist's utilization of a variety of approaches, which is closely related to the idea of an artist, media and technique. The manipulation of an artwork is based on the relationship of an artist, idea and media, through formalistic approaches and the surrounding community. Understanding of the visual identity is related to other disciplines in fine art, such as painting, printing and drawing, and new media because of the nature of its context, which is based on the physical form and space. The aim of this research is to generate knowledge on visual identity through sculpture. The research explores the forms and the symbolic meanings based on the influence of the local community and social system. This study employs the cultural concept as a system to create an understanding framework to the process of creating artwork. The qualitative approach is used as the methodology framework, which is deemed as suitable to the problem of investigating the visual identity in sculptures. The findings uncover that Malaysian sculptures synergize harmoniously the value system with modern expression, through belief, surroundings, needs and social requirements. These findings contribute to the knowledge of art, generally, that can be used in other fields of art in the process of creation and appreciation.
\end{abstract}

Keywords: culture; Malaysia; sculpture(s); visual identity; value system.

\section{$1 \quad$ Introduction}

Art forms in one main framework, beginning with the socio-cultural system, which consists of the concept of value, the environment, needs, the behaviour of artists and the social institutions. All these concepts will influence how an artwork exists and how it is embraced ${ }^{1}$.

Art exists, due to the need of humans to express the art within them through medias, ideas and experiences. Individuals with art in their heart are those who want to want to express their inner feelings to meet the basic needs of mankind.

\footnotetext{
${ }^{1}$ The term culture has a number of different meanings, all of them are valid for some uses. Sociologists take a much broader view of the term. For them, 'culture' refers to the total lifestyle of a people, including all the ideas, values, knowledge, behaviours and material objects that they share $[1,2]$
}

Received July $5^{\text {th }}, 2010$, Revised October $29^{\text {th }}, 2013$, Accepted for publication November $8^{\text {th }}, 2013$ Copyright (C) 2013 Published by LPPM ITB, ISSN: 1978-3078, DOI: 10.5614/itbj.vad.2013.4.1.6 
Certainly, every work of art has a specific shape and it can be moulded to understand its meaning [3].

On the other hand, in the context of environmental influence, an individual artist who produces artwork responds, due to the external reaction on the environment, causing individual artists in a society to interpret it in a distinctive shape and subsequently, shapes his own distinct basic concept through his behaviour while working.

Art is part of the cultural manifestations that exist in a society, based on the influence of its cultural environment, and thus, shapes its personality. The expression of artwork by an individual artist is the manifestation of the distinct culture of his society. In other words, the art of a society exists within the scope of its society that represents its culture ${ }^{2}$.

Because art is in a unified cultural system with its own distinct concepts, thus through the cultural approach, the researcher would like to reveal, understand and explain; form, meaning and the cultural identity of modern sculptures, as produced by Malaysian artists or sculptors.

\section{Objectives of the Research}

The purpose of this study is to explain and understand the socio-cultural system that is manifested visually by sculptors in modern Malaysian sculptures. In this context; values, beliefs, the environment, needs, social institutions and the behaviour of sculptors, as reflected in modern Malaysian sculptures will be identified. The purpose of this research is detailed, as follows:

1. explain the icons and symbols that are used, and the meaning that is reflected by modern Malaysian sculptures.

2. explain and understand the function of modern sculptures in Malaysia, i.e. in the context of the socio-cultural system of the people in this country.

3. explain the cultural identity that is manifested by sculptors in the designs and symbols of modern Malaysian sculptures.

\section{Research Methodology}

This study aims at understanding visual identity through modern Malaysian sculptures, based on the theory of culture. It is closely related to the values in belief, the physical socio- cultural environment, the need to produce artwork,

${ }^{2}$ E.B. Taylor defined culture as 'that complex whole which includes knowledge, belief, art, morals, law, custom and any other capabilities and habits acquired by man as a member of society'.[4] 
the role of the artist's behaviour and the social institutions within the community. The researcher used the paradigm qualitative approach and descriptive explanations.

The researcher believes that art-related studies should be guided by an appropriate research methodology, with the view of setting research methods to obtain valid information. In researching the visual identity of modern Malaysian sculptures, the researcher used an interdisciplinary approach, with the concepts in the theory of culture as the main theory (Grand Theory). In addition, the researcher also used the concepts in the theory of structural functionalism in the appreciation of art theory, i.e. to observe the form of modern Malaysian sculptures in the context of Malaysian society, based in its perpetuity and continuity.

\section{Literature Review and Theoretical Framework: Identity, Art and Culture}

"We live in a small world where identity matters. It matters both as a concept, theoretically, and as a fact of contemporary political life" [5]

Generally, identity is the identification of membership, based on individuals and subsequently, represents a group which is the identification to represent certain groups. Mankind exists based on identity groups, whether it is in the category of male or female identity. In life, every human being carries multiple identities. Zakaria Ali states that identity is a combination of value, the state of similarity and resemblance [6].

In the meaning of culture, the issue of identity in the context of art becomes more complex. The cultural approach as a system in understanding identity issues must be consistent, with cultural elements and concepts as the core. Consistency of approach is capable of explaining that meaning, because identity is something that is relatively dependent on the approach and the consistency in the way the concepts used are interpreted.

Identity is closely related to individuals and the social environment of a community. It is also the bond between the members or individuals with the community that tries to introduce the identity of the group. Symbols development and how an artwork is presented will be the major element in teaching and promoting equality and distinctiveness between groups within the community.

Identity is the term used to describe about existence and to place us, who are actively involved, in the explanation of historical events. Among the 
interpretation of identity is as a culture that is jointly owned and it is like the similarities of multiple selves that are shared by others in the community that has the same history and origin. Therefore, identity often describes the collective experience of historical origins, cultural codes and the way of life that is jointly owned by a group of people who become the main basis for the community within the framework and meaning of life that does not change and continues [7].

Identity is also a process that exists in one chain of continuous change. It is a historical display that is formed based on a chain of discontinuity, rather than a chain of continuity. Identity in this sense exists, either in the form of the conservations of the past and as a transformation and change in the future [8].

Identity is not simply the views of the past, which is characterized by its heritage in nature. It is also future oriented, one that goes through the process of creativity in the context of cultural change. Identity becomes the subject of the play of history, culture and continuous power that exist in the pattern and the nature of the typical self [9-12].

Based on the concept of identity, it is the process of art in the context of culture and is not free from the influence of the historical development of a race. It is also related to the existence of societal diversity in the context of communal globalization in Malaysia. Identity involves the issue of influence, change, transformation, interracial interaction, disputes, contradictions and a paradox of identity, which is dynamic, shifting and changing, as a result of a world formed by the strong situation of mutual dependency, strong influence and fierce competition between its elements [13].

The understanding regarding how identity exists, the paradigm that identity is founded upon, ideology in identity and how identity is used is very important for a country to develop its people. The way to develop, observe and use identity as the media must be present in the development of a people $[8,14]$.

When art is considered as one of the elements of culture, it thus includes ways and the aspect of the assignment of meaning, and comprehensive behaviour in expressing. The resultant environmental cultural behaviour and the concept of the need to express based on the artist's behaviour will demonstrate its distinct identity of art. It will clearly form the element of art that is themed upon existing cultural identity, i.e. based on the existing environment.

The assignment of symbols in artwork illustrates in the context of cultural multiplicity, which will touch on the issue of social and communal systems. This will then symbolically give meaning to works of art. The role of individual 
reactions in a specific group, based on pattern and social system will form the meaning from the symbolic interactions that lead to the formation of the identity of the group.

Identity of the art is represented by a certain system of symbols, based on its group. Symbolically, it will give meaning to the identity of the artwork, based on its group. The existence of the identity of the art, with the characterization of a distinctive design requires a mental framework that is consistent and parallel to common understanding.

The thoughts of Sigmund Freud say that at its initial stage, art exists because of individual psychological drive, based on personal norms and values. Onwards, the individual artist's behaviour manifests norms and values in the social and cultural systems. Additionally, the individual system that is based on the social environment acts individually, till it transcends personal norms and henceforth, a social identity and a bigger communal group that he represents emerge.

The identity of the art that is based on culture and guided by symbols is used in mutually agreed artwork. These artworks give certain meanings that point towards members that represent that community. The projection of these symbols is likely to manifest itself in terms of the occurrence of the process of artwork, based on the same style and moving towards the concept of identity of the community. It gives more exposure to symbols that lead to the identity of the communal group as a whole, as compared to the projection of identity that is based on individual symbols.

When we say that art is the reflection of culture, which represents a community or group, it is thus the pride of the communal group and enhances self-esteem. In order to improve self-esteem in the context of producing artwork, it is the responsibility of the artist to work towards its development and perpetuity, which will lead to the continuity of producing works of art. Although art is produced by individual artists, it represents his people, with its cultural symbols [3].

Each work of art appears to have a form and an icon, and does not only depend on factual meaning, which only revolves around formalistic aspects. It is also the result of the artist's expression; the symbolic meaning should also be examined. Studies on this implied meaning is called iconography, which is an approach to understand the symbols in physical artworks.

The combination of the three theories will shape the understanding and explanation of modern Malaysian sculptures, i.e. scholastically, theoretically, scientifically, and systematically (See Figure 1: The Merger of the Theory of 
Culture as a System). The concepts that are referred to as a fundamental interdisciplinary study become the main concept; as the early guide that is organized in a theoretical structure, as shown in Figure 1:

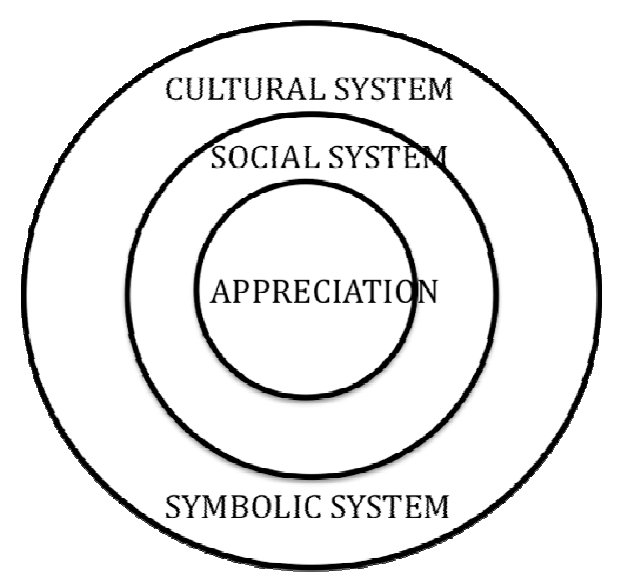

Figure 1 The Merger of the Theory of Culture as a System.

\section{Data Presentation and Analysis: Icons, Symbols and the Social System}

In modern Malaysia sculptures, traditional icons are used. Traditional icons in the context of cultural objects that are used by local communities are used as the icons in the works of modern Malaysian sculptures. The development of selected icons is very interesting, i.e. when sculptors use their knowledge in the use of strong arts language to create sculptures with distinct characteristics. Icons that are traditionally selected assign meaning to their artwork, highlighting the local community's issues and themes.

The influence on the development of local artwork as a result of national identity issues plays an important role in materializing sculptures with such forms. The issue of materializing form in representing national identity has been well expressed by the sculptors. As a result of observing the icons that exist in the works of modern Malaysian sculptures, it demonstrates the individual decision taken by Malaysian sculptors. Developing shapes from icons and local objects has become the trend in the production of modern Malaysian sculptures.

As a result of using local traditional icons, symbols that carry local meanings are created. Many modern Malaysian sculptures that are studied are the manifestation of cultural issues and phenomenon, way of life and the beauty of the Malaysian culture. 
The materialization of the shapes of modern Malaysian sculptures is the result of the relationship that is associated with the activity of the social system that is represented by the sculptors. It has been found that in shaping their artwork, the sculptors leverage on the issues that exist in the environment of their society. The sensitivity of Malaysian sculptors in the context of phenomenon and local issues is very strong. They often consider the local community's socio-cultural settings in their artwork.

To produce works of art that assign local meanings, the sculptors have symbolically used local issues and strong knowledge in the development of modern physical art language. The brilliance of the sculptors in visually connecting local issues and phenomenon is also the result of the education that is gained from existing arts studies institutions.

As a sculptor, they also have a high sense of responsibility towards the overall development of sculpting. They produce artwork with a sense of responsibility and awareness of the existing social values and cultural system. The concept of the need to express to fulfil personal goals is also in harmony with social needs.

In this context, educational institutions in the field of art play a major role in improving the development of sculpting. Likewise, other social institutions, aside from education, also play a role, such as at the primary and secondary education level.

\section{Summary of Findings: The Visual Identity of Modern Malaysian Sculptures}

The visual identity of modern Malaysian sculptures can be seen from several perspectives, i.e. through the cultural approach. First is from the values of belief perspective, which brings into being the distinct physical shape. It exists as a result of the local community's cultural icons. Local objects can create distinct characteristics, in which they become the main icon that will form the visual identity of modern Malaysia sculptures. Based on studies done with regard to the selection of main artworks that are often seen in the catalogues of exhibitions and exhibitions in galleries around Kuala Lumpur, it was found that the selection is based on Malay beliefs [1]. It can be seen in the shape of icons and objects that do not contradict the basis of Islam for the Malay community and also the identity requirements of the nation, based on the ethics of producing works of art.

In the context of the current development of physical art, where ethnic issues and recognition to the appearance of works of art that are based on the culture of various communities revives various traditions, and embed the drive and 
context of local elements into the overall display of physical artwork. Apart from that, through its relationship with the local community's social system, we can also visually recognize the existence of the identity of modern Malaysian sculptures. It must also be understood that the existence of visual shapes is also the symbolic reaction of the sculptor, which is subconsciously connected to the behaviour of the sculptor's immediate social system.

In displaying the existence of a variety of ethnics in Malaysia, the demonstration of icons and objects within the sculptures that were studied was based on the issue of only one group of people. This shows that Malaysian sculptors are not exposed to and do not adequately observe the culture of other communities that exist in Malaysia. The issue of knowledge and mutual understanding of other cultures that exist, based on the wealth of ethnicity is a loss in the context of the development of Malaysian physical artworks.

In addition, if viewed in the context of the current needs that are based on market requirements or national objectives in the production of artworks; the focus revolves around the identity that can represent the country. To solve this problem, artists take the shapes of traditional objects and the physicality of culture to represent national identity. Because of current needs based on national issues, it can be seen that the form of artwork is the same, in the context of objects and the issue of the production of artwork.

When we see from the perspective of contemporary technology, it can be clearly seen through the utilization of materials based on contemporary technology, components such as iron, cement and also 'stainless steel' skews towards the modern and contemporary. The use of natural materials is also found to be still relevant and is manipulated by sculptors to meet the needs, while competing to carve a niche in the modern market for artworks.

\section{References}

[1] Geertz, C. 1973. Description: Toward and Interpretive Theory of Culture, The Interpretation of Culture, New York: Basic Books.

[2] Kroeber, A.L. \& Kluckhohn, C. 1952. Culture: A Critical Review of Concepts and Definitions, Harvard University Peabody Museum of American Archeology and Ethnology Papers 47.

[3] Rohidi, T.R. 2000. Kesenian dalam Pendekatan Kebudayaan, Penerbit STSI, Bandung.

[4] Taylor, E.B. 1924 [orig. 1871]. Primitive Culture, 2, $7^{\text {th }}$ Ed, New York: Brentano's. 
[5] Gilroy, P. 1997. Diaspora and the Detours of Identity, in Woodward, K. (ed.), Identity and Difference: Culture, Media and Identities, London: Open University Press. pp. 299-346.

[6] Ali, Z. 1989. Seni dan Seniman, Esei-Esei Seni Halus, Kuala Lumpur: Dewan Bahasa dan Pustaka.

[7] Hall, S. 1990. Cultural Identity and Diaspora, in Jonathan Rutherford (ed.), Identity: Community, Culture, Difference, London: Lawrence and Wishart, pp. 222-37.

[8] Osman, M.T. 1988, The Concept of National Culture; The Malaysian Case, in Bunga Rampai: (Aspects of Malay culture), pp. 273-285, Kuala Lumpur: Dewan Bahasa dan Pustaka.

[9] Parsons, T. 1951. The Social System, New York, Free Press.

[10] Freud, E.L. 1970. The Letters of Sigmund Freud and Arnold Zweig, Int. Psycho-Anal. Lib., 84, London: The Hogarth Press and the Institute of Psycho-Analysis, pp. 1-184.

[11] Zaltman, G., Kotler, P. \& Kaufman, I. 1972. Creating Social Change, USA: Holt, Rinehart, Winston, Inc.

[12] Suparlan, P. 1982. Ilmu Sosial Dasar, Jakarta: UI Press.

[13] Piliang, Y.A. 2002. (Prolog), Identitas dan Budaya Massa: Aspek-Aspek Seni Visual di Indonesia, Yogyakarta: Yayasan Seni Cemeti.

[14] Koentjaraningrat. 1981. Pengantar Ilmu Antropologi, Jakarta: Rineka Cipta.

[15] Balai Seni Lukis Negara. 1996. Persoalan Tradisi \& Kemodenan: Pameran Seni Arca Kontemporari Malaysia, 8 April 1996 - 8 Mei 1996. 